\title{
The Characteristics of Modernism in The Wind Blows by Katherine Mansfield
}

\author{
Liu Xi, Zhou Yu-ying \\ Changchun University, Changchun, China
}

\begin{abstract}
Katherine Mansfield (1888-1923), born and brought up in colonial New Zealand, was a prominent modernist writer of short fiction. As one of England's most gifted short story writers, she was influenced over eight decades of writers. The Wind Blows, published in 1920, unfolds a meaningful story which was written to memorize her prime youth and homeland. The substances of the story on the material level come from the memories of Mansfield's native country, New Zealand. Furthermore, it was also a short story whose subject on the form level is based upon the winds blowing outside, corresponding with a little girl's delicate feelings. Mansfield probes the inner world of the characters and explores their feelings and thoughts from the perspectives of symbolism, stream of consciousness, and toning down of the plot. This paper aims to analyze the techniques of modernism in The Wind Blows from the perspective of symbolic significance, stream of consciousness, and toning down of the plot.
\end{abstract}

Keywords: modernism, symbolism, stream of consciousness

\section{Introduction}

Katherine Mansfield (1888-1923) is one of New Zealand's most celebrated authors who enjoys a widespread international reputation, and she is also regarded as the master of English short story in the 20th century. She pioneered many new literary techniques and exerted important influence on the evolution of the short stories in English. At the age of 19, Mansfield left New Zealand and settled down in the United Kingdom, where she was much influenced by modernist writers, such as James Joyce and Virginia Woolf. Mansfield went through infinite disappointments and pains during the first years in London, including those of loss of love, pregnancy, abortion, and illness. Nevertheless, it was exactly these dejected experiences that aroused her inspiration to create stories one after another which made up her first collection-In a German Pension.

The Wind Blows portrays a strong windy day, which contains five episodes of Matilda's life. At the beginning of the story, Matilda was woken up by the strong wind. She watched what happened on the street by the strong wind, including the wind raised iron, leaves, or newspaper, how two Chinese men lollopped in the wind, and how a white dog past the gate. Several minutes later, Matilda went to Mr. Bullen's home, who she fell in love secretly. After she got home, she was lost in various fancies and conjectures alone in the bedroom. In her daydream, her little brother Bogey called her out and took a walk on the esplanade. But the last one was an ephemeral illusory episode about when they grew up, they were on board leaning over the rail arm in arm. The five fragments are loosely connected with time and the wind runs through the whole story.

Liu Xi, M.A., lecturer, School of Foreign Languages, Changchun University.

Zhou Yu-ying, B.A. candidate, School of Foreign Languages, Changchun University. 
The paper analyzes how Mansfield makes use of several techniques in The Wind Blows. First, the paper discusses the features of symbolism and how Katherine Mansfield endued her own particular feelings and significance endowed these symbols to have special meanings. Then, the stream of consciousness was reflected by internal focalization to present the inner thoughts and feelings of the characters vividly. Finally, the paper explores the technique of constructing plot.

\section{Symbolic Significance of the Wind and the Flower}

Symbolism is the writing technique of using symbols, which is widely used by writers. Symbolism is no mere idle fancy or corrupt degeneration; it is inherent in the very texture of human life. Language itself is a symbolism. It arose in France in the last half of the 19th century and greatly influenced many English writers. Symbolism, in the history of literature, can be defined as the literature movement reacting against realism in France in the mid-to-late 19th century, or as a school of French symbolist in the late 19th century, or being a rhetorical writing technique. Generally speaking, symbolism can be defined as "the practice of representing things by means of symbols or of attributing symbolic meanings or significance to objects, events or relationships" (Xu, 2007, p. 7). In other words, symbolism can be taken as a device to represent or convey the characters' private thought and emotion through the use of concrete images- the symbols. These concrete images can be everything - any object that is lively or lifeless, a person, even a scene, or a place, while the meaning these images carry can be the abstract ideas, an emotion, a belief, a value, a feeling, or an attitude. What a symbol is carrying on is decided by writers themselves.

In The Wind Blows, Katherine Mansfield used many symbols to endue the characters her particular emotions and significance. Moreover, she endowed these symbols with special meanings. For example, the wind symbolized a fetter chaining their pace and the chrysanthemum symbolized a youth panic in their adolescence.

The essence of wind is no more than the ventilation of the air, that is, we can merely feel it but fail to see it. Katherine Mansfield used some images to explore the meaning of the wind. "SUDDENLY—dreadfully—she wakes up. What has happened? Something dreadful has happened. No-nothing has happened" (Mansfield, 1998, p. 74). When there was a strong wind outside, the sound of it awoke Matilda with a start and also blew her adolescent excited heart. Owing to the wind, she could not have her music class with Mr. Bullen; due to the wind, she had to put up with mom and grandma's annoying words. At that moment, the wind was a chain which confined her to home. She felt a great desire to escape from. There would never be smooth sailing for the road to growth and maturity. The wind is a kind of impediment on this process, which would stop her step.

In this sense, the wind stands for the girl's feelings in her heart-rebellious and uncontrolled. What is more, the moment she got to Mr. Bullen's house, the wind seems to blow over. However, as for her, the wind would never cease blowing. It is evident that it represented a teenage girl's yearning for the opposite sex and rejection of her feelings through Mr. Bullen's teaching. "What an extraordinary thing. Her fingers tremble so that she can't undo the knot in the music satchel. It's the wind ..." (Mansfield, 1998, p. 75). Matilda was enchanted with her inextricable secret love which was in the depth of heart. On the other hand, the wind is also a symbol of the youth that swifts away quickly. Matilda and Bogey were on the way to esplanade, they even could not walk fast in the wind. However, they did say, "Come on! Come on! Let's get near" (Mansfield, 1998, p. 75). What they approached nearly was their eagerness to acquire freedom. Wind belongs to natural power, so that man cannot control it, just as Matilda and Bogey cannot stop their growing pace. After that, the author just 
used a short ephemeral illusory episode to express how time flies, "How many years ago". As the wind is gone, their youth is gone.

Flower is one of most common symbols in Katharine Mansfield's fictions. Chrysanthemum is usually linked to youth panic and vernal sorrow. It is not a seeming writing but owns its profound meaning. In The Wind Blows:

Marie Swainson runs into the garden next door to pick the "chrysanthemums" before they are ruined. Her skirt flies up above her waist; she tries to beat it down, to tuck it between her legs while she stoops, but it is no use - up it flies. All the trees and bushes beat about her. She picks as quickly as she can, but she is quite distracted. She does not mind what she does - she pulls the plants up by the roots and bends and twists them, stamping her foot and swearing. (Mansfield, 1998, p. 75)

In The Wind Blows, the chrysanthemum symbolized a peculiar youth panic in frenzy. The panic was uncontrolled with incomprehension in the girl's deep heart, because she did not understand why she picked the chrysanthemum. That is, her mind was almost out of control though. She never expected the chrysanthemum to be ruined. How unwilling she was to let the beauty go. "She likes this room. It smells of art serge and stale smoke and chrysanthemums ... there is a big vase of them on the mantelpiece behind the pale photograph of Rubinstein" (Mansfield, 1998, p. 76). Matilda thought Mr. Bullen's house was a cozy harbor to stay after she escaped from her home. The big vase in his house filled with chrysanthemums was a symbol of the girl's happiness. Nevertheless, for she was in her adolescence, she also conceived "Life is so dreadful" for this secret love.

\section{Stream of Consciousness Presented in The Wind Blows}

Stream of consciousness is a style of writing used in fictions that shows the continuous flow of a character's thoughts and feelings without using the usual methods of description or conversation. It was used particularly in the 20th century by writers. The term "stream of consciousness" was coined by philosopher and psychologist William James in The Principles of Psychology:

Consciousness, then, does not appear to itself as chopped up in bits ... it is nothing joined; it flows. A "river" or a "stream" is the metaphors by which it is most naturally described. In talking of it hereafter, let us call it the stream of thought, consciousness, or subjective life. (James, 1990, p. 5)

Stream of consciousness draws support from internal monologue and free association to describe the flow of consciousness without control, independent of time of space. People who are in the process of conscious activity cannot focus on one point for a long time. The reason is that it is influenced by free association, and there are three elements which can control the free association, including memory, feeling, and imagination. Memory is the basis of three elements and feeling makes the association move on and imagination can ensure the flexibility of free association.

Typically, there are several examples to illustrate the consciousness of the character in The Wind Blows caused by free association. The form of expression is a ring which both links the beginning and the ending. All the associations come from the wind connected with the wind. Matilda, the protagonist, began with free association which so as to be her consciousness to flow to suggest what she felt and where she was at all times.

The wind, the wind. It is frightening to be here in her room by herself. The bed, the mirror, the white jug and basin gleam like the sky outside. It is the bed that is frightening. There it lies, sound asleep... Does Mother imagine for one 
moment that she is going to darn all those stockings knotted up on the quilt like a coil of snakes? She is not. No, Mother. I do not see why I should! ... The wind - the wind! There is a funny smell of soot blowing down the chimney. Has not anyone written poems to the wind? ... "I bring fresh flowers to the leaves and showers." ... What nonsense. (Mansfield, 1998, p. 77)

Matilda was scared to hear the sound of the wind. Consequently, she shifted her attention to everything in the room, the bed, the mirror, the jug, and the gleam, everything she saw in the room was viewed as something terrible in the outside world. At that time, her consciousness traced back to the wind inside. As she saw the bed, she found some socks lying on bed, which made her imagine a picture in which her mother would let her darn all those stockings. How she flied a rage at it! And then, she had an idea that there was a funny smell of soot blowing down the chimney by the wind. Her consciousness was jerked back to wind right now. Finally, she thought "Has not anyone written poems to the wind?" which associated her "I bring fresh flowers to the leaves and showers" (Mansfield, 1998, p. 77). Matilda thought critically such verse was truly boring. When she prepared to continue her association, her little brother Bogey called her out. It is obvious that in The Wind Blows, the association of Matilda by the wind, was really rich and complex. Mansfield utilized internal monologue to reveal inner world and free association direct to express the process of their consciousness flowing.

When Matilda and Bogey went to the esplanade, they talked with each other. Matilda thought that it was funny to hear Bogey's breaking voice. Soon, her thoughts turned back to the wind that carried their voices. The use of free association is revealed expertly to go beyond the superficial significance of the words in the text.

\section{Toning Down of the Plot}

Modernist literature belongs to the part of 20th century capitalist culture, which does not advocate the use of the work to reproduce life, but to promote the psychological feelings from people's inner world, the performance of life to people's repression and distortion. In the modernist literature, the characters are often deformed, the story is often absurd, and the theme is often desperate. Katherine Mansfield uses for reference from modernistic writing skills and brings forth new ideas in short fictions.

Compared with the traditional literature which considers the plot to be most important, modern short stories focus on the mission of mirroring society and human lives just through some segments or may just by internal ideas of characters. Without any doubt, Mansfield is skillful for that. Her "episode" or "slice of life" technique is more or less taken for granted, but her stories are really the significance in English to be written without the conventional plot. She replaces the expected writing pattern of beginning, rising action, climax, and ending by concentration on a moment or episode or loosely linked series of moments. The interest lies not in what happens but in why it happens.

By showing readers a character at a particular moment, Katherine Mansfield allows the reader to imagine what happens and why it happens. There is no step-by-step development and ups-and-downs of plot in her story, but it does not mean, as one critic has said, we are not moved by the story since nothing happens to her characters, or just may be moments of the souls desperate choice, the moment of crisis, external or internal. "Her stories may seem to be formless but actually there is a careful pattern of things" (Alpers, 1982, p. 12).

The weakening of plots is a kind of feature of modernism in Mansfield's works. Her fictions pay more attention to characters' inner activity and spiritual world rather than the development of the plot. In The Wind Blows, the story has almost no complete structure and coherent plot. That is, it is constituted by some memory 
fragments. A certain mood of the protagonist plays a more important role than the traditional plot. The work is connected with "present" and "past" by several memory episodes. The wind revolves from beginning to the ending. "The wind, the wind" appears three times. Such lyric words create a rhythm like a poem. The author catches an instant as the frame of The Wind Blows to represent the elapse of time.

The story describes two windy days, one is in the past and the other is that moment. On past day, Matilda had her music lesson, when she faced to Mr. Bullen, there were some complex feelings-grievance, adoration, and gingerliness. The other windy day, Matilda was lost in various fancies and conjectures alone in the room. Her little brother Bogey called her out. The two similar days and different scenes are linked up naturally and poetically.

Look, Bogey, there is the town. Does not it look small? There is the post office clock chiming for the last time. There is the esplanade where we walked that windy day. Do you remember? I cried at my music lesson that day — how many years ago! Good-bye, little island, good-bye.... (Mansfield, 1998, p. 79)

Mansfield used the lyric words as the end of the story, which shows that the time is fleeting through the two similar scenes. The readers would be unavoidable to sigh how time went by so quickly. A simple windy day overlapped the past and the moment.

\section{Conclusion}

Katherine Mansfield used some typical modernism techniques in The Wind Blows, especially the symbolism, the stream of consciousness, and the toning down of plot. For the symbolism, the images of wind and chrysanthemums are most clearly. Katherine Mansfield used some techniques of stream of consciousness such as internal monologue and free association to reveal the subtle changes of the characters' inner world. For the toning down of plot, Mansfield, by giving us glimpse of a character at a specific time or moment, explores the inner world freely. The plot in her works was still and free flowing without following the time order of clock strictly, it mainly depended on the thoughts of characters to develop the clue. Such modernist techniques make The Wind Blows filled with poetic meaning, and Katherine Mansfield plays a very important role in the development of modern short fiction. Although Mansfield had a short life span, her contributions to the development of modern fiction have been largely taken for granted.

\section{References}

Alpers, A. (1982). The life of Katherine Mansfield. Oxford, U.K.: Oxford University Press. Gerald, G. (1980). Narrative discourse: An essay in method. Ithaca: Cornell University Press. James, W. (1990). The principles of psychology. Cambridge, M.A.: Harvard University Press. Kobler, J. K. (1990) Katherine Mansfield: A study of the short fiction. Boston, M.A.: Twayne Publishers. Mansfield, K. (1998). Selected stories. Oxford, U.K.: Oxford University Press.

Raman, S. (2004). A reader's guide to contemporary literary theory. Beijing: Foreign Language Teaching and Research Press. Stead, C. K. (1977). The letter and journals of Katherine Mansfield. London, U.K.: Thomas Allen \& Son. Wilfred, L. G. (2004). A handbook of critical approaches to literature. Beijing: Foreign Language Teaching and Research Press. $\mathrm{Xu}, \mathrm{H}$. (2007). The discussion of modernist art in Katherine Mansfield's short stories. Yunnan: Yunnan University Press.

Yu, W. X. (2002). Cultural study: An introduction. Beijing: People's Press. 